\title{
Aktivitas Antibakteri Sediaan Sabun Wajah Cair Ekstrak Herba Pegagan (Centella asiatica (L.) Urban) terhadap Pertumbuhan Propionibacterium acnes dan Staphylococcus aureus
}

\section{Antibacterial Activity Of Liquid Face Wash From Centella asiatica (L.) Urban Extract Against Propionibacterium acnes and Staphylococcus aureus}

\author{
Trisiana Tri Soebagio ${ }^{1}$, Yustina Sri Hartini ${ }^{2}$, Exsyupransia Mursyanti ${ }^{1 *}$ \\ ${ }^{1}$ Program Studi Biologi, Fakultas Teknobiologi, Universitas Atma Jaya Yogyakarta \\ Jl. Babarsari no. 44, Sleman, Daerah Istimewa Yogyakarta, Indonesia \\ ${ }^{2}$ Program Studi Farmasi, Fakultas Farmasi, Universitas Sanata Dharma \\ Kampus III, Paingan, Maguwoharjo, Depok, Sleman, Daerah Istimawa Yogyakarta, Indonesia \\ Email: e.mursyanti@uajy.ac.id \\ *Penulis Korespondensi
}

\begin{abstract}
One of the many skin diseases experienced by teenagers is acne. Some of the bacteria that causes acne is Propionibacterium acnes and Staphylococcus aureus. Therefore, treatment can be carried out using antibiotics. However, excessive use of antibiotics can be used as a side effect because it does not match the skin. One of the natural plant ingredients that can be used as an alternative to antibiotics, is gotu kola (Centella asiatica (L.) Urban) herbs. This natural ingredient is usually applied in topical dosage forms. The purpose of this study was to study the composition of flavonoids, tannins and triterpenoids included in gotu kola herb extracts and to find out liquid facial wash using gotu kola herb extracts, and to find out how liquid face wash preparations of gotu kola herb extracts in the growth of $S$. aureus and $P$. acnes. Gotu kola herb extracts are $20 \%, 30 \%$, and $40 \%, 50 \%$ and $60 \%$. Stages of research carried out are plant research, poder making and extraction of Centella asiatica (L.) Urban herb, qualitative and quantitative test of Centella asiatica (L.) Urban herb extract, sterilization of media, purity testing, antibacterial, antibacterial extract of Centella asiatica (L.) Urban herb extract, liquid face wash preparations and evaluation of face wash. The evaluation parameters of liquid facial swash preparations are $\mathrm{pH}$, high foam, viscosity, and homogenity. The results obtained from phytochemical analysis are Centella asiatica (L.) Urban herb extracts containing flavonoids and tannins but do not contain triterpenoids. The quality of liquid face wash preparations Centella asiatica (L.) Urban herb extract which is stored for 28 days with parameters pH, high foam, viscosity and homogenity meet SNI. Liquid face wash Centella asiatica (L.) Urban herb extract has antibacterial power against the bacteria $S$. aureus and $P$. acnes.
\end{abstract}

Key Word : Centella asiatica, face wash, evaluation, phytochemical, Propionibacterium acnes, Staphylococcus aureus

\begin{abstract}
Abstrak
Salah satu penyakit kulit yang banyak dialami oleh remaja yaitu jerawat. Bakteri penyebab jerawat diantaranya adalah Propionibacterium acnes dan Staphylococcus aureus. Oleh karena itu, jerawat dapat diobati dengan menggunakan antibiotik. Namun, penggunaan antibiotik yang berlebihan dapat menyebabkan munculnya efek samping seperti iritasi karena tidak cocok dengan kulit. Salah satu bahan alami tanaman obat yang dapat digunakan sebagai alternatif menggantikan antibiotik, adalah herba pegagan (Centella asiatica (L.) Urban). Bahan alami ini biasanya diaplikasikan dalam bentuk sediaan topikal. Tujuan penelitian adalah mengetahui kandungan flavonoid, tanin dan triterpenoid yang terdapat dalam ekstrak herba pegagan serta mengetahui karakteristik sabun wajah cair dengan penambahan ekstrak herba pegagan, dan mengetahui kemampuan sediaan sabun wajah cair ekstrak herba pegagan dalam menghambat pertumbuhan bakteri $S$. aureus dan $P$. acnes. Perlakuan konsentrasi yang digunakan dalam pengujian aktivitas antibakteri ekstrak maupun sediaan sabun wajah cair ekstrak herba pegagan yaitu $20 \%$, 30\%, dan 40\%, $50 \%$ dan $60 \%$. Tahapan penelitian yang dilakukan yaitu identifikasi tanaman,
\end{abstract}


pembuatan serbuk dan ekstraksi herba pegagan, uji kualitatif dan kuantitatif ekstrak herba pegagan, pembuatan dan sterilisasi medium, uji kemurnian bakteri, uji aktivitas antibakteri ekstrak dan sediaan sabun wajah cair ekstrak herba pegagan, pembuatan sediaan sabun wajah cair dan evaluasi sediaan. Parameter evaluasi sediaan sabun wajah cair yaitu pH, tinggi busa, viskositas, dan homogenitas. Hasil yang didapatkan dari analisis fitokimia adalah ekstrak herba pegagan mengandung flavonoid dan tanin namun tidak mengandung triterpenoid. Kualitas dari sediaan sabun wajah cair ekstrak herba pegagan yang disimpan selama 28 hari memiliki parameter $\mathrm{pH}$, tinggi busa, viskositas dan homogenitas memenuhi SNI. Sabun wajah cair ekstrak herba pegagan memiliki daya antibakteri terhadap bakteri S. aureus dan P. acnes.

Kata Kunci : pegagan, sabun wajah, evaluasi, fitokimia, Propionibacterium acnes, Staphylococcus aureus

Diterima: 12 Februari 2020, disetujui: 7 Mei 2020

\section{Pendahuluan}

Salah satu penyakit kulit yang banyak dialami oleh remaja yaitu jerawat. Jerawat disebabkan oleh bakteri Propionibacterium acnes yang berperan dalam patogenesis jerawat (Jain et al., 2002). Beberapa antibiotik yang biasa digunakan untuk mengobati jerawat yaitu klindamisin, tetrasiklin, dan lainnya. Namun, penggunaan antibiotik berlebihan dapat menyebabkan resistensi (Jain et al., 2002). Oleh karena itu, perlu alternatif lain untuk mengobati jerawat, yaitu berasal dari bahan alam berupa tanaman obat.

Salah satu tanaman obat di Indonesia yang memiliki antibakteri untuk melawan bakteri penyebab jerawat adalah pegagan(Centella asiatica (L.) Urban). Hal ini didukung dengan kandungan bioaktif pada pegagan yang mempunyai aktivitas antibakteri, seperti flavonoid, tanin, saponin, dan lainnya (Sutardi, 2016).

Kemudahan aplikasi dari ekstrak herba pegagan pada pengobatan jerawat, dapat dibuat dalam salah satu bentuk sediaan yaitu sabun wajah cair. Sabun cair adalah salah satu sediaan farmasi yang dapat dipilih untuk membersihkan kulit dari bahan sabun yang tidak berbahaya. Hal ini disebabkan karena penggunaan sabun wajah cair lebih efisien untuk menghilangkan kotoran yang terdapat pada permukaan kulit (SNI, 1996).

Karakteristik sabun wajah cair yang dibuat harus memenuhi persyaratan dari SNI agar aman digunakan untuk kulit. Berdasarkan Badan Standarisasi Nasional (1996), penampakan dari sabun wajah cairyang baik adalah memiliki $\mathrm{pH}$ antara 4,5-7,8 dan viskositas antara 3.000-50.000 cPs. Berdasarkan hal yang dikemukakan oleh Erawati et al. (2016) dan Harry (1973) bahwa sabun wajah cair yang baik adalah homogen dan tinggi busa berkisar 1,3-22 cm.

Berdasarkan hal yang telah dijelaskan di atas maka perlu dilakukan penelitian lebih lanjut untuk mengetahui aktivitas antibakteri ekstrak pegagan dalam bentuk sabun wajah cair terhadap Propionibacterium acnes dan Staphylococcus aureus.

\section{Metode Penelitian}

\section{Identifikasi Tanaman Pegagan}

Identifikasi tanaman C. asiatica (L.) Urban dilakukan oleh Balai Besar Penelitian dan Pengembangan Tanaman Obat dan Obat Tradisional, Tawangmangu.

\section{Ekstraksi Herba Pegagan}

Serbuk pegagan sebanyak 50 gram di tambah etanol $70 \%$ sebanyak $500 \mathrm{~mL}$ (perbandingan 1:10), kemudian ditutup dengan alumunium foil dan selama 2 hari dilakukan pengadukan 1x24 jam dalam shaker incubator. Sampel disaring dengan kertas saring setelah dua hari, kemudian didapatkan filtrat dan ampas pertama yang dihasilkan dari sampel, ampas pertama kemudian diremaserasi kembali dengan etanol $70 \%$ dalam shaker incubator selama 1x24 jam.

Filtrat yang diperoleh kemudian diuapkan menggunakan rotary evaporator suhu $60{ }^{\circ} \mathrm{C}$ selama 2 jam hingga didapatkan ekstrak herba pegagan. Ekstrak yang dihasilkan kemudian dimasukkan kedalam 
oven sampai etanol menguap. Ekstrak kental kemudian ditimbang dan disimpan pada wadah tertutup. Rendeman ekstrak dihitung menggunakan rumus :

Perhitungan rendemen $=\frac{\text { massa ekstrak }}{\text { massa serbuk }} \times 100 \%$

\section{Uji Fitokimia Kualitatif (Flavonoid, Tanin,} dan Triterpenoid) (Harbone, 1987)

Uji flavonoid kualitatif diawali dengan menimbang ekstrak sebanyak 0,1 gram ditambahkan $2 \mathrm{~mL}$ etanol 70\%, dan air panas yang telah dididihkan sebanyak $50 \mathrm{~mL}$ kemudian ditambahkan 0,05 gram logam $\mathrm{Mg}$, 1 tetes larutan $\mathrm{HCl}$ pekat dan 5 tetes amil alkohol. Hasil positif ditunjukkan dengan terbentuknya warna jingga atau kuning

Uji tanin kualitatif diawali dengan menimbang ekstrak sebanyak 0,1 gram ditambah etanol $70 \%$ sebanyak $2 \mathrm{~mL}$, kemudian ditambah 3 tetes $\mathrm{FeCl}_{3}$. Hasil positif dari pengujian ini yaitu terbentuk warna biru, biru-hijau atau hijau, dan terbentuk endapan

Uji triterpenoid kualitatif diawali dengan menimbang ekstrak sebanyak 0,1 gram ditambah etanol $70 \%$ sebanyak $2 \mathrm{~mL}$, lalu dimasukkan ke dalam droplet, kemudian ditambahkan dengan 3 tetes asetat anhidrat dan 1 tetes $\mathrm{H}_{2} \mathrm{SO}_{4}$ pekat. Hasil positif dari triterpenoid yaitu jika terbentuk warna cokelat, merah, ungu dan terbentuk cincin.

\section{Uji Fitokimia Kuantitatif (Flavonoid dan Tanin) (Roy et al., 2018)}

Uji flavonoid kuantitatif diawali dengan pembuatan larutan standar kuersetin dengan cara standar kuersetin ditimbang $10 \mathrm{mg}$ dan dilarutkan dalam $10 \mathrm{~mL}$ methanol menjadi 1000 ppm. Larutan standar kuersetin diambil sebanyak $1 \mathrm{~mL}$ dan ditambah $9 \mathrm{~mL}$ metanol menjadi $100 \mathrm{ppm}$. Larutan dibuat variasi konsentrasi yaitu 20 ppm, 40 ppm, 60 ppm, 80 ppm, dan 100 ppm. Setiap konsentrasi ditambahkan $3 \mathrm{~mL}$ metanol, $0,2 \mathrm{~mL} \mathrm{AlCl}_{3}$ $10 \%, 0,2 \mathrm{~mL}$ kalium asetat $1 \mathrm{M}$, dan ditambahkan dengan akuades hingga $10 \mathrm{~mL}$ kemudian diinkubasi selama 30 menit pada suhu ruang. Hasil absorbansi diukur dengan spektrofotometer pada panjang gelombang 431 nm. Kurva baku standar selanjutnya dibuat.

Tahapan selanjutnya adalah penetapan kadar flavonoid dalam ekstrak pegagan yang dilakukan dengan cara menimbang ekstrak sebanyak $100 \mathrm{mg}$ dan dilarutkan dalam $10 \mathrm{~mL}$ metanol. Larutan kemudian diambil $1 \mathrm{~mL}$ dan ditambahkan dengan $3 \mathrm{~mL}$ metanol, 0,2 $\mathrm{mL}$ kalium asetat dan diberikan akuades hingga 10 $\mathrm{mL}$, lalu inkubasi pada tempat gelap pada suhu ruang selama 30 menit. Absorbansi diukur dengan spektrofotometri pada panjang gelombang $435 \mathrm{~nm}$. Kadar total flavonoid dihitung dengan rumus :

$$
\mathrm{TFC}=\frac{\mathrm{R} \times \mathrm{D} . \mathrm{F} \mathrm{XV} \mathrm{X} 100}{\mathrm{~W}}
$$

Keterangan :

$\mathrm{R}$ = hasil kurva

D.F $=$ faktor pengenceran

$\mathrm{V}=$ volume simplisia

$\mathrm{W}$ = berat total simplisia yang digunakan $(\mathrm{g})$

Uji tanin kuantitatif diawali dengan pembuatan larutan standar asam galat dengan cara asam galat ditimbang $5 \mathrm{mg}$ kemudian dimasukkan ke dalam labu ukur. Folin Ciocalteau dan $\mathrm{Na}_{2} \mathrm{CO}_{3} 35 \%$ diambil masingmasing sebanyak $0,5 \mathrm{~mL}$ dan $1 \mathrm{~mL}$ kemudian ditambahkan ke dalam labu ukur. Labu ukur kemudian ditambahkan dengan akuades hingga tanda batas dan digojog. Larutan dalam labu ukur kemudian dituangkan ke dalam tabung reaksi dengan variasi konsentrasi 20, 30, 40, 50, dan $60 \mathrm{ppm}$, lalu ditambahkan akuades secukupnya sampai total larutan menjadi $5 \mathrm{~mL}$.

Tabung reaksi masing-masing kemudian di vortex dan diinkubasi selama 30 menit sampai 1 jam. Absorbansi dianalisis menggunakan spektrofotometer pada panjang gelombang $725 \mathrm{~nm}$. Kemudian dilakukan pembuatan kurva baku standar.

Tahapan selanjutnya adalah penetapan kadar tanin dalam ekstrak pegagan yang dilakukan dengan cara menimbang ekstrak. Ekstrak herba pegagan dibuat menjadi larutan stok dengan konsentrasi 500 ppm. Ekstrak pegagan kemudian dituang pada tabung reaksi secukupnya dan ditambahkan dengan Folin Ciocalteau dan $\mathrm{Na}_{2} \mathrm{CO}_{3} 35 \%$ diambil masingmasing sebanyak $0,5 \mathrm{~mL}$ dan $1 \mathrm{~mL}$. Tabung reaksi kemudian divortex dan diinkubasi selama 30 menit sampai 1 jam. Absorbansi dianalisis dengan menggunakan spektrofotometer dengan panjang gelombang $725 \mathrm{~nm}$. Kadar total tanin dihitung dengan rumus : 
Total tanin $\mathrm{GAE}=\frac{\mathrm{c}}{(\mathrm{V} / \mathrm{m})}$

Keterangan :

$\mathrm{c}=$ konsentrasi total tanin dari kurva standar $(\mathrm{mg} / \mathrm{L})$

$\mathrm{V}=$ volume ekstrak $(\mathrm{L})$

$\mathrm{m}=$ berat ekstrak $(\mathrm{g})$

\section{Uji Antibakteri Ekstrak dan Sediaan Sabun Wajah Cair Ekstrak Herba Pegagan (Handayani et al., 2012 dengan modifikasi)}

Starter dibuat dahulu sebelum dilakukan uji aktivitas antibakteri. Kultur bakteri uji yang telah murni diambil sebanyak 1 ose dan dimasukkan dalam $10 \mathrm{~mL}$ medium NB. Erlenmeyer ditutup dengan kapas dan dibungkus dengan kertas payung. Starter bakteri $P$. acnes dan $S$. aureus diinkubasi selama 48 jam dalam inkubator. Kultur bakteri $P$. acnes diambil sebanyak $1000 \mu \mathrm{L}$ dan diinokulasikan dalam medium NA dengan metode pour plate. Kultur bakteri $S$. aureus diambil sebanyak $100 \mu \mathrm{L}$ dan diinokulasikan dalam medium NA dengan metode spread plate. Medium dibuat 5 sumuran dengan perforator no. 3 untuk bakteri S. aureus.

Masing-masing sumuran diisikan dengan klindamisin $0,1 \%$ (kontrol positif), ekstrak pegagan dengan konsentrasi 20\% sampai $40 \%$, dan etanol (kontrol negatif) masing-masing sebanyak $20 \mu \mathrm{L}$. Pengulangan dilakukan sebanyak 5 kali. Medium dibuat dengan 1 sumuran masing-masing dilubangi dengan perforator no. 3 untuk bakteri $P$. acnes sebanyak 5 petri. Medium pertama sumuran diisi dengan ekstrak pegagan dengan konsentrasi $20 \%$ sebanyak $20 \mu \mathrm{L}$, medium kedua sumuran diisi dengan ekstrak pegagan dengan konsentrasi 30\% sebanyak $20 \mu \mathrm{L}$, medium ketiga diisi dengan ekstrak pegagan dengan konsentrasi $40 \%$ sebanyak $20 \mu \mathrm{L}$. Medium keempat sumuran diisi dengan klindamisin $0,1 \%$ (kontrol positif) sebanyak 20 $\mu \mathrm{L}$ dan etanol (kontrol negatif) sebanyak 20 $\mu L$. Pengulangan dilakukan sebanyak 5 kali. Medium diinkubasi pada inkubator anaerob dengan suhu $37^{\circ} \mathrm{C}$ selama 24 jam untuk $P$. acnes dan S. aureus. Luas zona hambat diukur dan dihitung.

\section{Formulasi Sabun Wajah Cair}

Sodium Laureth Sulfat (SLES) dilarutkan ke dalam air diaduk hingga homogen kemudian $\mathrm{NaCl}$ ditambahkan sampai tercampur rata (sebagai adonan 1 (C)). Asam stearat dilarutkan dengan gliserin pada gelas pyrex dan dipanaskan hingga meleleh, dimasukkan adepslanae dan triethanolamin secara bergantian sambil diaduk hingga tercampur semua (sebagai adonan 2).

Adonan 1 dimasukkan ke dalam adonan 2. Adonan diaduk hingga tercampur semua. Adonan ditambahkan air sedikit demi sedikit sambil diaduk hingga tercampur semua. Adonan diangkat dan didiamkan sampai pada suhu ruang $(\mathrm{G})$. Ekstrak herba pegagan dimasukkan ke dalam adonan setelah dingin sambil diaduk. Adonan sabun cair dimasukkan ke dalam botol kaca. Hal yang sama diulangi pada pembuatan sabun cair dengan perbedaan ekstrak pegagan selanjutnya. Larutan (C) dicampurkan ke dalam larutan $(G)$ sedikit demi sedikit, dan diaduk hingga larut (Nurama, 2014).

\section{Uji Sediaan Sabun Wajah Cair}

Uji sediaan meliputi uji stabilitas sediaan (viskositas, tinggi busa, dan $\mathrm{pH}$ ) dan uji homogenitas. Uji viskositas sediaan dilakukan dengan cara sampel uji ditempatkan dalam gelas beker sebanyak $500 \mathrm{~mL}$ kemudian dipasang spindel jenis nomor tiga. Hasil pengukuran kemudian dicatat (Fitriansyah et al., 2016 dengan modifikasi).

Uji tinggi busa dilakukan dengan cara sediaan sebanyak $1 \mathrm{~mL}$ ditambahkan dengan 9 $\mathrm{mL}$ akuades kemudian divortex selama 2 menit. Tinggi busa yang diperoleh diukur dengan penggaris (Ichsani, 2016).

Uji pH dilakukan dengan mengambil sediaan sebanyak $1 \mathrm{~mL}$ dan ditambah dengan 9 $\mathrm{mL}$ akuades. Selanjutnya elektroda dicelupkan hingga angka $\mathrm{pH}$ meter konstan. Hasil pembacaan skala dicatat dan setelah selesai pengujian elektroda dibilas dengan akuades. Pengujian diulangi sebanyak 5 kali (Mumpuni dan Heru, 2017).

\section{Uji Antibakteri Sediaan Sabun Wajah Cair}

Starter dibuat dahulu sebelum dilakukan uji aktivitas antibakteri. Kultur bakteri uji yang telah murni diambil sebanyak 1 ose dan 
dimasukkan dalam $10 \mathrm{~mL}$ medium NB. Erlenmeyer kemudian ditutup dengan kapas dan dibungkus dengan kertas payung. Starter bakteri $P$. acnes dan $S$. aureus diinkubasi selama 48 jam dalam inkubator.

Antibakteri S. aureus dilakukan dengan cara kultur bakteri S. aureus diambil sebanyak $100 \mu \mathrm{L}$ dan diinokulasikan dalam medium NA dengan metode spread plate. Metode antibakteri yang digunakan adalah metode paper disc. Kertas saring yang digunakan dimasukkan (direndam) dalam sediaan sabun kontrol, sabun $20 \%$, sabun $30 \%$, sabun $40 \%$, dan sabun komersial. Kertas saring yang telah direndam kemudian diletakkan diatas medium NA dan dipastikan telah menempel pada permukaan.

Medium diinkubasi dengan inkubator pada suhu $37^{\circ} \mathrm{C}$ selama 24 jam. Zona hambat diukur dengan penggaris. Luas zona hambat yang terbentuk dihitung.

\section{Analisis Data}

Analisis data akan diolah dengan menggunakan SPSS versi 15. Analisis yang digunakan yaitu oneway ANOVA (Analysis of Varians) dengan tingkat kepercayaan 95\%, kemudian dilanjutkan dengan analisis DMRT untuk melihat letak dari beda nyata (Fitriansyah et al., 2016).

\section{Hasil dan Pembahasan}

Kadar air dari serbuk pegagan yang didapatkan dari Balai Besar Penelitian dan Pengembangan Tanaman Obat dan Obat Tradisional Tawangmangu Karanganyar sebesar 7,15\%. Kadar sesuai dengan standar untuk kadar air simplisia yaitu $<10 \%$ (Sayuti, 2015). Ekstrak yang diperoleh adalah ekstrak kental dengan warna cokelat kehitaman yang dapat dilihat pada Gambar 1.

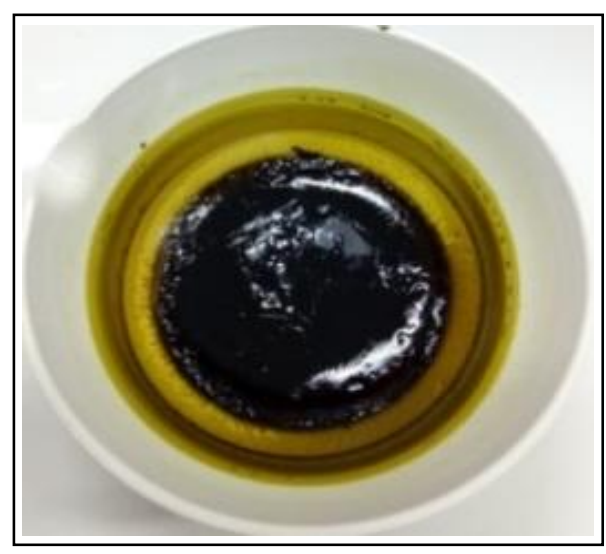

Gambar 1. Ekstrak herba pegagan

Rendemen ekstrak yang dihasilkan dalam 5 kali pengulangan didapatkan perhitungan rendemen sebanyak $37 \%$.

Uji fitokimia secara kualitatif adalah salah satu cara yang dapat digunakan untuk menentukan senyawa aktif dalam herba pegagan yang dapat digunakan sebagai antibakteri (Mulyanti et al., 2015). Uji fitokimia yang diuji adalah senyawa metabolit sekunder flavonoid dan tanin. Hasil uji fitokimia kualitatif dapat dilihat pada Tabel 1.

Tabel 1. Uji Fitokimia Kualitatif

\begin{tabular}{ccccc}
\hline \hline Metabolit Sekunder & Hasil Uji & Keterangan \\
\hline \hline Flavonoid & + & Terbentuk warna kuning, jingga \\
\hline Tanin & + & Terbentuk warna hijau kehitaman \\
\hline Triterpenoid & & - & Tidak terbentuk warna cokelat \\
\hline Hasil & ini sesuai dengan & yang & & mengandung saponin, flavonoid, dan tanin. \\
dikemukakan & oleh Sutardi $(2016)$, yang & & Hasil pengujian triterpenoid pada ekstrak herba \\
menyatakan & bahwa tanaman pegagan & & pegagan menunjukkan hasil negatif yang
\end{tabular}


ditandai dengan tidak ada perubahan warna menjadi coklat.
Berdasarkan pengujian flavonoid kuantitatif yang telah dilakukan, maka didapatkan hasil pada Gambar 2.

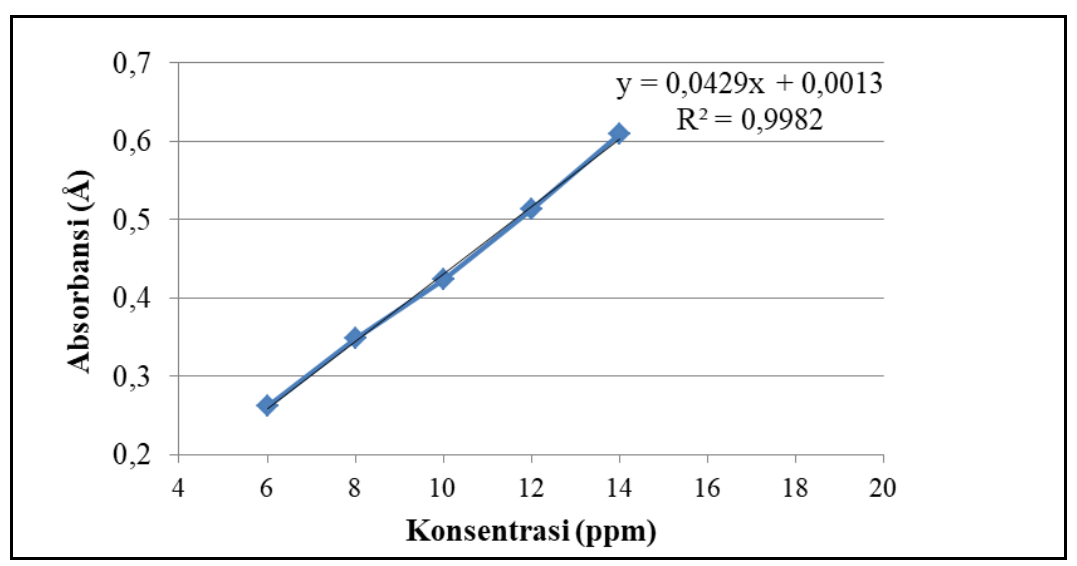

Gambar 2. Kurva absorbansi kuersetin

Hasil persamaan yang didapatkan yaitu $\mathrm{y}=0,0429 \mathrm{x}+0,0013$. Dengan nilai $\left(\mathrm{r}^{2}\right)$ sebesar 0,9982. Nilai (r2) ini mendekati 1 yang berarti persamaan regresinya adalah linear. Menurut Umar (2000), nilai $\left(\mathrm{r}^{2}\right)$ sama dengan satu maka terjadi hubungan linear yang sempurna yang berupa garis lurus. Kadar flavonoid total yang didapatkan dalam ekstrak herba pegagan yaitu $2,8392 \mathrm{mg} \mathrm{QE} / \mathrm{mg}$ ekstrak.

Berdasarkan pengujian tanin kuantitatif yang telah dilakukan, maka didapatkan hasil pada Gambar 3.

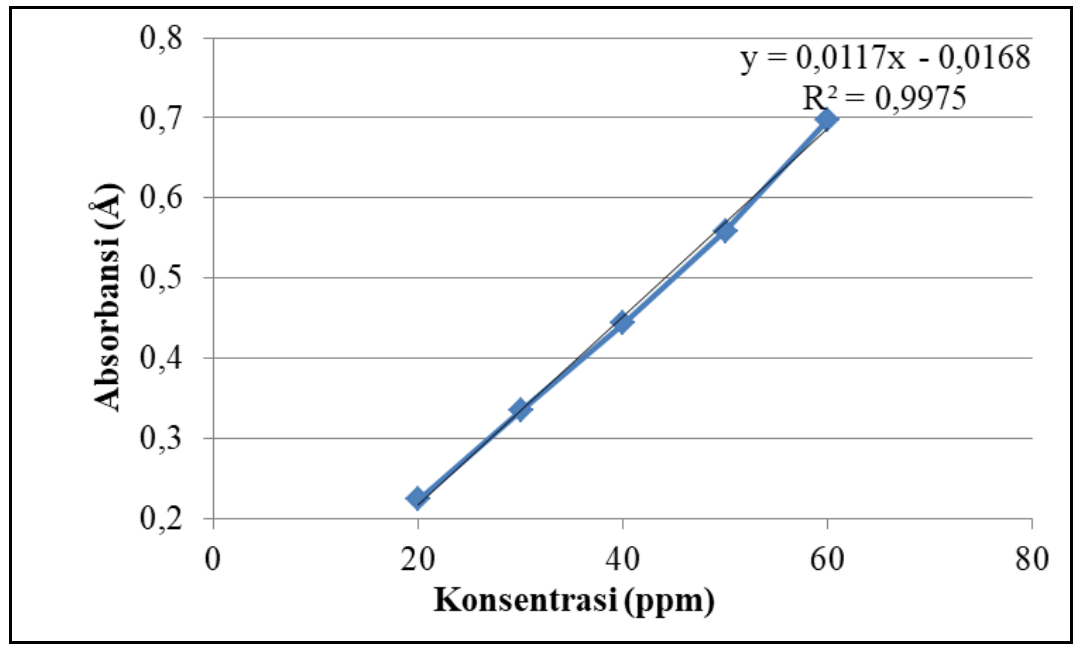

Gambar 3. Kurva absorbansi tanin

Hasil persamaan yang didapatkan untuk tanin kuantitatif yaitu $\mathrm{y}=0,117 \mathrm{x}-0,0168$ dengan nilai $\left(\mathrm{r}^{2}\right)$ sebesar 0,9975 . Dengan nilai $\left(r^{2}\right)$ sebesar 0,9982 . Nilai $\left(r^{2}\right)$ ini mendekati 1 yang berarti persamaan regresinya adalah linear. Menurut Umar (2000), nilai $\left(\mathrm{r}^{2}\right)$ sama dengan satu maka terjadi hubungan linear yang sempurna yang berupa garis lurus. Kadar total tanin dalam ekstrak herba pegagan yaitu 0,0375 mg GAE/mg ekstrak.

Ekstrak herba pegagan yang dihasilkan diukur aktivitas antibakterinya terhadap bakteri uji yaitu $S$. aureus dan $P$. acnes. Hasil zona hambat bakteri $S$. aureus dapat dilihat pada Tabel 2. 
Tabel 2. Luas zona hambat $\left(\mathrm{cm}^{2}\right)$ ekstrak herba pegagan terhadap bakteri $S$. aureus pada perlakuan kontrol, konsentrasi 20\%, 30\%, dan 40\%.

\begin{tabular}{cc}
\hline \hline Konsentrasi & Luas Zona Hambat $\left(\mathbf{c m}^{2}\right)$ S. aureus \\
\hline \hline Kontrol positif (klindamisin) & $8,2068^{\mathrm{b}}$ \\
\hline $20 \%$ & $2,0104^{\mathrm{a}}$ \\
\hline $30 \%$ & $2,4151^{\mathrm{a}}$ \\
\hline $40 \%$ & $3,2020^{\mathrm{a}}$ \\
\hline
\end{tabular}

Berdasarkan Tabel 2, luas zona hambat ekstrak herba pegagan dengan konsentrasi $20 \%$, 30\%, dan 40\% lebih kecil dibandingkan dengan perlakuan kontrol positif (antibiotik klindamisin) dan berbeda nyata dengan $20 \%$,
30\%, dan 40\%. Perlakuan konsentrasi $40 \%$ memiliki kecenderungan untuk menghambat lebih besar bakteri $\mathrm{S}$. aureus dibandingkan dengan perlakuan konsentrasi $20 \%$ dan $30 \%$.

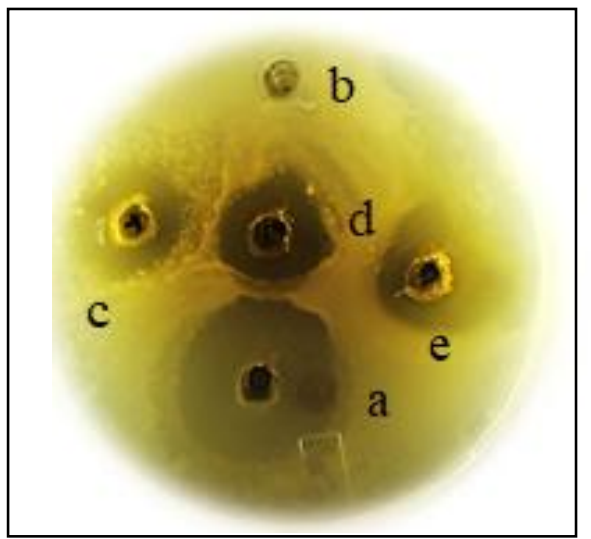

Gambar 4. Zona hambat ekstrak herba pegagan terhadap pertumbuhan S. aureus: a) kontrol Positif; b) kontrol negatif; c) $20 \%$; d) $30 \%$; e) $40 \%$.

Berdasarkan Gambar 4, membuktikan bahwa ekstrak herba pegagan dapat menghambat $S$. aureus. Luas zona hambat dengan konsentrasi $40 \%$ yang didapatkan pada penelitian ini lebih besar yaitu sebesar 3,2020 $\mathrm{cm} 2$ dibandingkan dengan penelitian Dewi (2012), luas zona hambat ekstrak etanol pegagan dengan konsentrasi $50 \%$ yang terbentuk sebesar $1,86 \mathrm{~cm} 2$. Zona hambat yang terbentuk klindamisin lebih besar dari perlakuan penambahan ekstrak, hal ini disebabkan antibiotik ini sangat efektif dalam penghambatan bakteri gram positif seperti pada golongan bakteri Staphylococcus sp. (Nugroho, 2013). Hasil uji aktivitas antibakteri bakteri $P$. acnes dapat dilihat pada Tabel 3 .

Tabel 3. Luas zona hambat $\left(\mathrm{cm}^{2}\right)$ ekstrak herba pegagan terhadap bakteri $P$. acnes pada perlakuan kontrol, konsentrasi $20 \%$, 30\%, dan $40 \%$.

\begin{tabular}{cc}
\hline \hline Konsentrasi & Luas Zona Hambat $\mathbf{c m}^{\mathbf{2}) \text { P. acnes }}$ \\
\hline \hline Kontrol positif (klindamisin) & $6,0492^{\mathrm{a}}$ \\
\hline $20 \%$ & $6,0755^{\mathrm{a}}$ \\
\hline $30 \%$ & $7,1423^{\mathrm{a}}$ \\
\hline $40 \%$ & $18,4879^{\mathrm{b}}$ \\
\hline
\end{tabular}

Berdasarkan Tabel 3, luas zona hambat ekstrak herba pegagan terhadap $P$. acnes memiliki efek penghambatan yang besar pada perlakuan penambahan ekstrak $40 \%$. Hasil berbeda nyata dengan perlakuan kontrol positif (klindamisin) dan penambahan ekstrak 20\% dan $30 \%$. Luas zona hambat untuk bakteri $P$. acnes dapat dilihat pada Gambar 5 dan hasil evaluasi $\mathrm{pH}$ yang dilakukan selama 28 hari dapat dilihat pada Gambar 6 


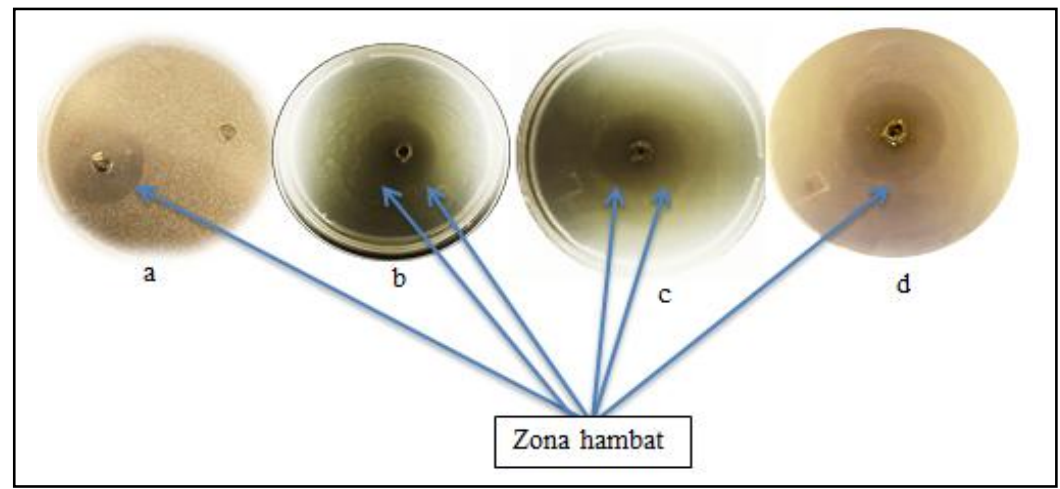

Gambar 5. Zona hambat ekstrak herba pegagan terhadap pertumbuhan P.acnes setelah inkubasi 19 Jam: a) kontrol positif; b) 20\%; c) $30 \%$; d) $40 \%$.

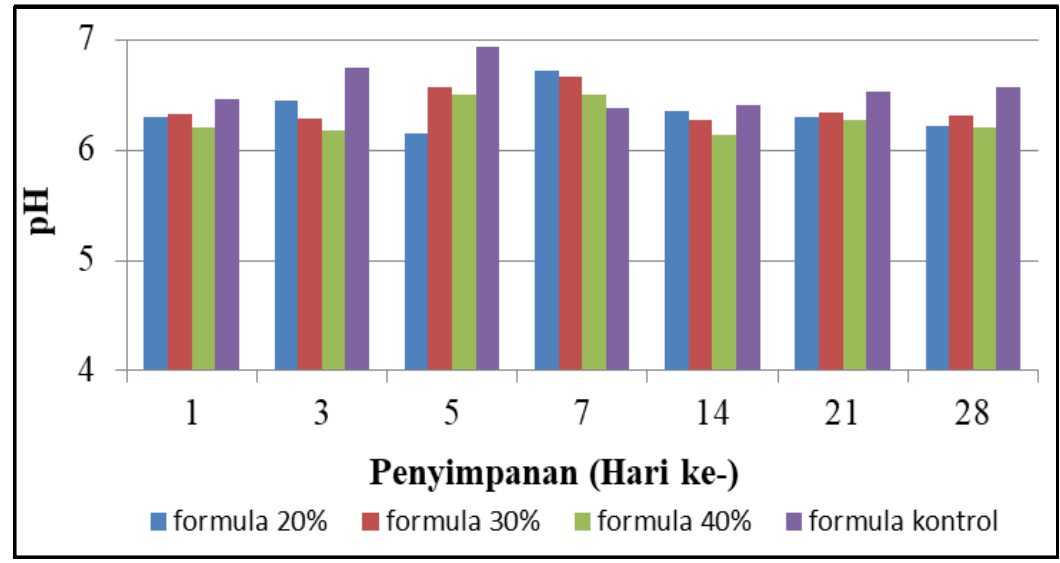

Gambar 6. Hasil nilai pH sediaan sabun cair ekstrak herba pegagan dengan variasi kontrol, 20\%, $30 \%$ dan $40 \%$ pada hari ke 1, 3, 5, 7, 14, 21, dan 28.

Berdasarkan Gambar 6, pH sediaan berfluktuasi pada semua perlakuan. Nilai $\mathrm{pH}$ sediaan yang didapatkan pada penelitian ini berkisar 6,0-6,92. Namun, nilai $\mathrm{pH}$ yang didapatkan ini masih masuk kedalam rentang nilai $\mathrm{pH}$ kulit yang baik menurut SNI untuk sediaan sabun wajah cair.

Hasil evaluasi tinggi busa yang dilakukan selama 28 hari dapat dilihat pada Gambar 7.

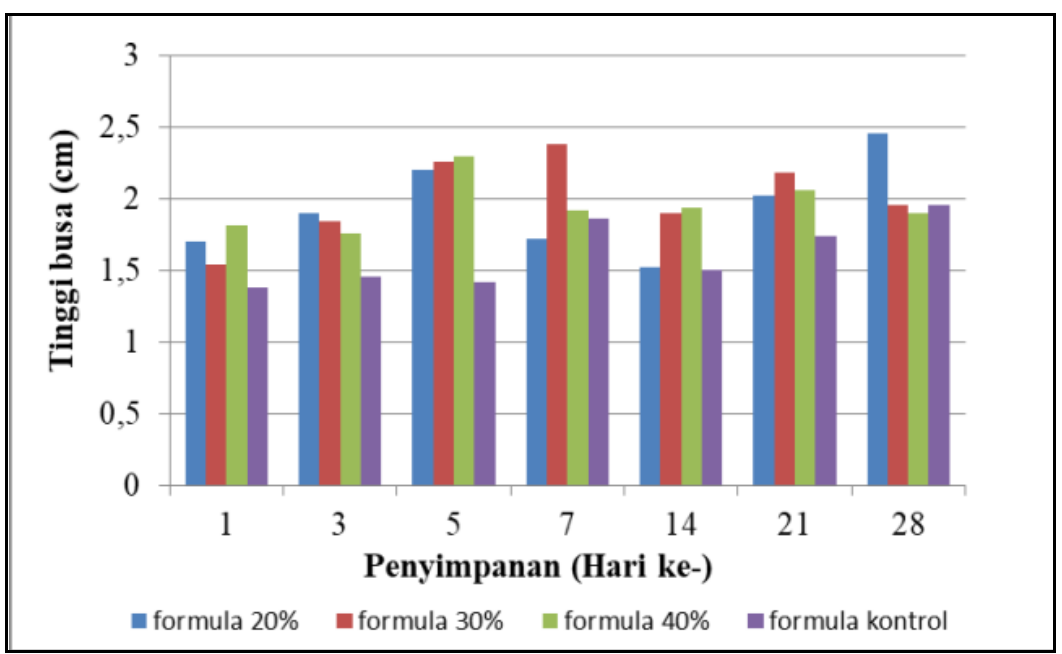

Gambar 7. Hasil nilai tinggi busa sediaan sabun cair ekstrak herba pegagan dengan variasi kontrol, $20 \%, 30 \%$ dan $40 \%$ pada hari ke $1,3,5,7,14,21$, dan 28 . 
Hasil uji tinggi busa mengalami fluktuasi. Penurunan tinggi busa yang terjadi disebabkan karena bahan surfaktan yang digunakan sedikit dan humektan dengan jumlah yang tinggi sehingga dapat mengakibatkan adanya penurunan tinggi busa (Budianto, 2010). Selain itu, penggunaan asam stearat yang terlalu banyak dapat mengakibatkan sabun kurang berbusa (Priani \& Yani, 2010).

Evaluasi viskositas sediaan sabun wajah cair yang telah disimpan selama 28 hari dapat diliihat pada Gambar 8.

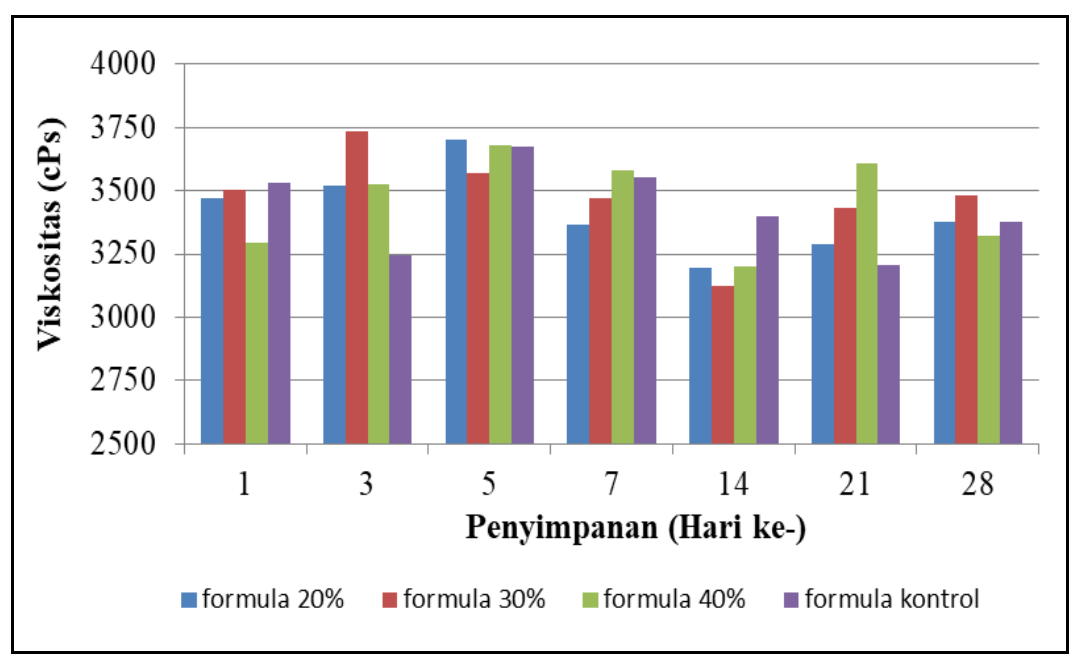

Gambar 8. Hasil nilai viskositas sediaan sabun cair ekstrak herba pegagan dengan variasi kontrol, 20\%, 30\% dan 40\% pada hari ke 1, 3, 5, 7, 14, 21, dan 28 .

Hasil pada Gambar 8 dapat dilihat bahwa viskositas sediaan mengalami fluktuasi. Namun, fluktuasi dari viskositas masih memenuhi standar sediaan sabun wajah cair yang baik menurut SNI. Penurunan viskositas sediaan yang dialami disebabkan karena gliserin yang bersifat higroskopis yang berpengaruh karena menyerap uap air dari luar dan mengakibatkan air dalam sediaan bertambah banyak (Rowe et al., 2009).

Nilai viskositas yang mengalami kenaikan dapat disebabkan karena bahan SLES. SLES adalah bahan yang mengakibatkan larutan akan semakin kental diantara turunan alkil sulfat yang lainya karena
SLES di dalam sediaan sabun dapat mengubah sifat fisik dari larutan seperti kelarutan pada air, viskositas, dan efek kekentalan.

Hasil yang didapatkan selama masa simpan 28 hari yaitu pada keempat sediaan sabun wajah cair ekstrak herba pegagan adalah homogen. Hasil pengujian homogen sesuai dengan pernyataan Erawati et al., (2016), bahwa hasil evaluasi homogenitas sediaan yang baik adalah tidak terlihat butiran kasar pada permukaan kaca objek.

Berdasarkan hasil perhitungan, didapatkan luas zona hambat bakteri Staphylococcus aureus yang dapat dilihat pada Tabel 4.

Tabel 4. Luas zona hambat $\left(\mathrm{cm}^{2}\right)$ sediaan sabun wajah cair ekstrak herba pegagan terhadap bakteri S. aureus pada perlakuan kontrol, konsentrasi $20 \%, 30 \%$, dan $40 \%$.

\begin{tabular}{cc}
\hline \hline Perlakuan Sediaan & Luas Zona Hambat $\left(\mathbf{c m}^{2}\right)$ S. aureus \\
\hline \hline Sabun kontrol (tanpa ekstrak) & $5,4412^{\mathrm{a}, \mathrm{b}}$ \\
\hline Sabun komersial & $4,1691^{\mathrm{a}}$ \\
\hline Sabun 20\% & $5,4440^{\mathrm{a}, \mathrm{b}}$ \\
\hline Sabun 30\% & $5,8066^{\mathrm{b}}$ \\
\hline Sabun 40\% & $6,3848^{\mathrm{b}}$ \\
\hline Sabun 50\% & $4,4376^{\mathrm{a}}$ \\
\hline Sabun 60\% & $4,4863^{\mathrm{a}}$ \\
\hline
\end{tabular}


Hasil yang didapatkan dari Tabel 4 didapatkan konsentrasi $40 \%$ memiliki efek penghambatan yang paling besar untuk bakteri $S$. aureus dibandingkan dengan semua perlakuan. Hal ini disebabkan karena konsentrasi ekstrak yang digunakan cukup tinggi sehingga menghasilkan zona hambat yang besar. Sediaan sabun wajah cair dibuat lebih besar konsentrasinya yaitu 50\% dan $60 \%$ (Tabel 4).
Berdasarkan hasil yang ditunjukkan pada Tabel 4 diketahui bahwa pada semua perlakuan baik kontrol (tanpa ekstrak), komersial, sabun dengan penambahan ekstrak $50 \%$ dan $60 \%$ tidak memiliki perbedaan yang nyata. Namun demikian sabun dengan ekstrak $60 \%$ memiliki kecenderungan untuk menggantikan sabun komersial. Luas zona hambat pada bakteri $S$. aureus dapat dilihat pada Gambar 9.

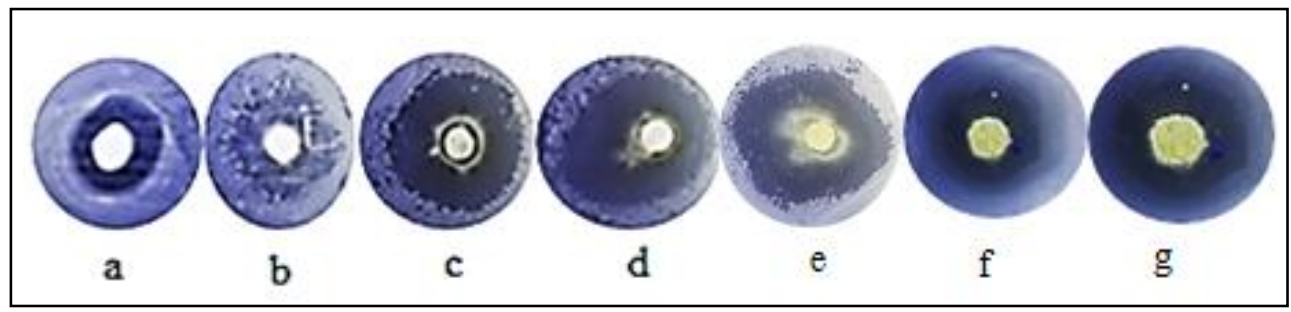

Gambar 9. Zona hambat sediaan sabun wajah cair terhadap pertumbuhan Staphylococcus aureus: a) sediaan komersial; b) sediaan kontrol tanpa ekstrak; c) sediaan 20\%; d) sediaan 30\%; e) sediaan 40\%; f) sediaan $50 \%$; g) sediaan $60 \%$.

Berdasarkan Gambar 9, sediaan sabun wajah cair ekstrak herba pegagan memiliki potensi yang lebih besar dalam menghambat $S$. aureus dibanding sabun komersial yang digunakan karena bahan yang digunakan dapat menghambat. Zona hambat sediaan kontrol tanpa ekstrak cukup besar untuk bakteri $S$. aureus. Namun, efek penghambatan dari sediaan kontrol hanya bertahan sampai 18 jam inkubasi, selanjutnya zona bening dapat ditumbuhi $S$. aureus kembali. Hasil ini menunjukkan aktivitas antibakteri bersifat bakteriostatik yaitu cara untuk menghambat pertumbuhan bakteri namun tidak membunuh.

Berdasarkan hasil perhitungan, didapatkan luas zona hambat bakteri $P$. acnes yang dapat dilihat pada Tabel 5 .

Tabel 5. Luas zona hambat $\left(\mathrm{cm}^{2}\right)$ sediaan sabun wajah cair ekstrak herba pegagan terhadap bakteri $P$. acnes pada perlakuan kontrol, konsentrasi $20 \%, 30 \%$, dan $40 \%$.

\begin{tabular}{cc}
\hline \hline Perlakuan Sediaan & Luas Zona Hambat $\left(\mathbf{c m}^{\mathbf{2}}\right)$ S. aureus \\
\hline \hline Sabun kontrol (tanpa ekstrak) & $2,2267^{\mathrm{a}}$ \\
\hline Sabun komersial & $2,5870^{\mathrm{a}, \mathrm{b}}$ \\
\hline Sabun $20 \%$ & $2,7039^{\mathrm{a}, \mathrm{b}}$ \\
\hline Sabun 30\% & $2,9854^{\mathrm{b}, \mathrm{c}}$ \\
\hline Sabun $40 \%$ & $3,3476^{\mathrm{c}}$ \\
\hline Sabun $50 \%$ & $2,3793^{\mathrm{b}}$ \\
\hline Sabun $60 \%$ & $2,4103^{\mathrm{b}}$ \\
\hline
\end{tabular}

Data pada Tabel 5, menunjukkan bahwa sabun dengan penambahan ekstrak $40 \%$ berbeda nyata dengan sabun kontrol (tanpa ekstrak maupun sabun komersial). Sediaan sabun wajah cair dibuat yang lebih besar konsentrasinya yaitu 50\% dan 60\% (Tabel 5).

Hasil yang didapatkan pada Tabel 5, menunjukkan bahwa pada semua perlakuan baik sabun kontrol, komersial, dan sabun dengan konsentrasi $50 \%$ dan $60 \%$ tidak berbeda nyata. Hal ini menunjukkan bahwa dengan penambahan ekstrak baik $50 \%$ dan $60 \%$ dapat menggantikan sabun komersial meskipun luas zona hambat tidak berbeda nyata. Luas zona hambat bakteri $P$. acnes dapat dilihat pada Gambar 10. 


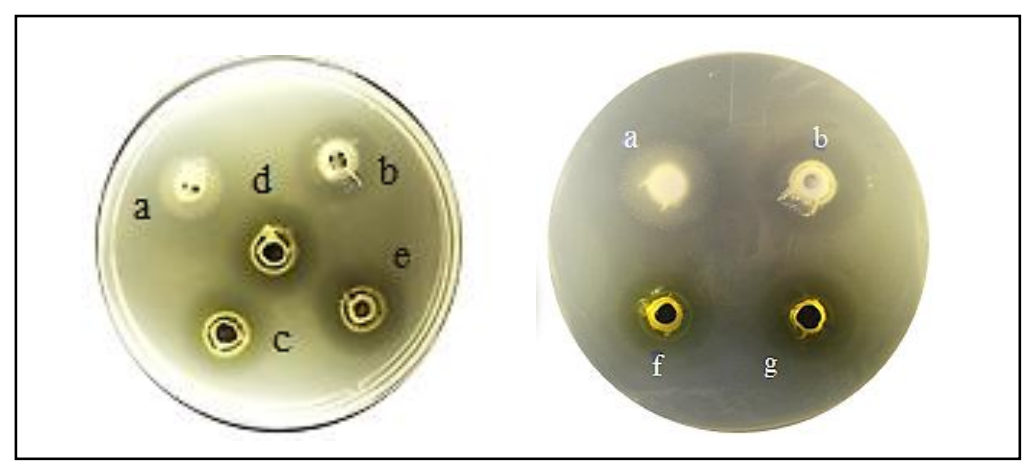

Gambar 10. Zona hambat sediaan sabun wajah cair terhadap pertumbuhan Propionibacterium acnes : a) sediaan komersial; b) sediaan kontrol tanpa ekstrak; c) sediaan 20\%; d) sediaan $30 \%$; e) sediaan $40 \%$; f) sediaan $50 \%$;g) sediaan $60 \%$.

Berdasarkan Gambar 10 terbentuk zona hambat oleh bakteri $P$. acnes pada sabun komersial karena sabun komersial yang digunakan mengandung ekstrak pegagan dan asam laurat. Asam laurat berfungsi sebagai antibakteri karena asam laurat memiliki aktivitas antibakteri yang sangat kuat pada bakteri Gram positif (Solomon \& Alan, 1996).

\section{Simpulan}

Ekstrak herba pegagan mengandung flavonoid dan tanin namun tidak mengandung triterpenoid. Sabun wajah cair memiliki karakteristik: $\mathrm{pH}$ kisaran 6,3 - 6,4; tinggi antara 1,5 - $2 \mathrm{~cm}$; viskositas antara 3400-3500 cPs dan sabun wajah cair bersifat homogen setelah penambahan ekstrak pegagan selama 28 hari. Semua karakteristik sabun wajah cair memenuhi SNI dan sediaan sabun wajah cair ekstrak herba pegagan dengan konsentrasi $40 \%$ memiliki kemampuan dalam menghambat pertumbuhan bakteri S. aureus dan P. acnes.

Uji lanjutan dapat dilakukan untuk pengujian iritasi primer dengan menggunakan hewan percobaan, uji organoleptik untuk sediaan sabun wajah cair, penelitian dengan penambahan konsentrasi sediaan sabun wajah cair sehingga zona hambat lebih baik dan menjaga pemanasan agar tidak melebihi suhu $70^{\circ} \mathrm{C}$ saat pembuatan sediaan sehingga senyawa dalam ekstrak yang digunakan tidak rusak.

\section{Ucapan Terima Kasih}

Penulis mengucapkan terima kasih kepada Besar Penelitian dan Pengembangan Tanaman
Obat dan Obat Tradisional Tawangmangu Karanganyar yang telah membantu penelitian.

\section{Daftar Pustaka}

Badan Standardisasi Nasional. 1996. SNI 06-40851996 SNI 16-4380-1996 Tentang Standar Mutu Pembersih Kulit Wajah. Badan Standardisasi Nasional, Jakarta.

Badan Standardisasi Nasional. 1996. SNI 06-40851996 Tentang Standar Mutu Sabun Mandi Cair. Badan Standardisasi Nasional, Jakarta.

Budianto, V. 2010. Optimasi formula sabun transparan dengan humectant gliserin dan surfaktan cocoamidopropyl betaine: aplikasi desain faktorial. Skripsi S-1. Fakultas Farmasi Universitas Sanata Dharma, Yogyakarta.

Dewi, S. S. 2012. Daya hambat ekstrak etanol daun pegagan (Centella asiatica L.) terhadap pertumbuhan iolat methicillin-resistant Staphylococcus aureus dari sputumrn penderita pneumonia. Skripsi S-1. Fakultas Kedokteran Universitas Syiah Kuala, Banda Aceh.

Erawati, E., Pratiwi, D. dan Zaky, M. 2016. Pengembangan formulasi dan evaluasi fisik sediaan krim ekstrak etanol 70\% daun labu siam (Sechium edule (Jacq.) Swatz). Farmagazine 3(1) : 11-20.

Fitriansyah, S.N., Wirya, S. dan Hermayanti, C. 2016. Formulasi dan evaluasi spray gel fraksi etil asetat pucuk daun teh hijau (Camelia sinensis [L.] Kuntze) sebagai antijerawat. Pharmacy 13(2) : 202 - 216.

Handayani, N., Wartono, M.W., dan Murti, R.K. 2012. Identifikasi dan uji aktivitas antibakteri fraksi teraktif daun mimba 
(Azadirachta indica A. Juss). ALCHEMY Jurnal Penelitian Kimia 8(1): 57-69.

Harborne, J. B. 1987. Metode Fitokimia. ITB Bandung, Bandung.

Harry, R. G. 1973. Harry's Cometicology. Leonard Hill Books, London.

Ichsani, N. N. 2016. Formulasi sediaan sabun wajah minyak atsiri kemangi (Ocimum basilicum L.) dengan kombinasi sodium lauril sulfat dan gliserin serta uji antibakteri terhadap Staphylococcus epidermidis. Skripsi S-1. Fakultas Farmasi Universitas Muhammadiyah, Surakarta.

Jain, A., Sangal, L., Basal, E., Kaushal, G. P., Agarwal, S. K. 2002. Anti-inflammatory effect of erythromycin and tetracycline on Propionibacterium acnes induced production of chemotatic factors and reactive oxygen species by human neutrophils. Dermatology Online Journal 8 (2) $: 1-10$.

Mulyanti, D., Rismawati, E., Maulana, I.T., Febriani, D. dan Dewi, Y. N. 2015. Uji aktivitas ekstrak etanol daun sirsak (Annona muricata L.) pada bakteri Propionibacterium acnes, Staphylococcus aureus dan Staphylococcus epidermidis. Prosiding Penelitian. Akademika Unisba Kesehatan dan Farmasi, Bandung.

Mumpuni, A. S. dan Heru, S. 2017. Mutu sabun transparan ekstrak etanol herba pegagan (Centella asiatica L.) setelah penambahan sukrosa. Pharmaciana 7(1):71-78.

Nugroho, R. A. 2013. Terapi topikal klindamisin dibandingkan dengan niacinamide + zinc pada Acne vulgaris. Skripsi S-1. Universitas Diponegoro, Semarang.
Nurama, Y. 2014. Pengaruh penambahan sari belimbing wuluh terhadap sifat fisik sediaan sabun wajah berbentuk cair. e-Journal UNS $3(1): 251-259$.

Priani, S. E. dan Yani, L. 2010. Pembuatan sabun transparan berbahan dasar minyak jelantah serta hasil uji iritasinya pada kelinci. Prosiding Penelitian. Unisba, Bandung.

Rowe, C. R., Paul, J. S. dan Marian, E. 2009. Handbook Of Pharmaceutical Excipients 6th Edition. London Pharmaceutical Press, London.

Roy, A. R., Laxmi, K. M. dan Navneeta, B. 2018. Qualitative and quantitative phytochemical analysi of Centella asiatica. Natural Products Chemistry and Research Article 6(4) : 1-4.

Sayuti, N. A. 2015. Formulasi dan uji stabilitas fisik sediaan gel ekstrak daun ketepeng cina (Cassia alata L.). Jurnal Kefarmasian Indonesia 5(2) : 74-82.

Solomon, B. A. dan Alan, S. R. 1996. Effect of detergents on acne. Clinics in Dermatology 14(1): 95-99.

Sutardi. 2016. Kandungan bahan aktif tanaman pegagan dan khasiatnya untuk meningkatkan sistem imun tubuh. Jurnal Litbang Pertanian 35(3) : 121-130.

Umar, H. 2000. Metode Penelitian untuk Skripsi dan Tesis Bisnis. Raja Grafindo Persada, Jakarta. 